Academic Essay in Economics

\title{
Effects of Unemployment Caused by Pandemic
}

\author{
Zirui Deng1,* \\ ${ }^{1}$ Bishop Ready High School, Columbus, USA \\ *Correspondence: 3400963662@qq.com
}

(Received: 12/17/2020; Accepted: 01/21/2021; Published: 01/28/2021)

DOI: https://doi.org/10.37906/isteamc.2021.3

\begin{abstract}
As COVID-19 spreads around the world, global financial markets are volatile. Faced with the severe situation of the rapid spread of the epidemic overseas, many countries have taken active prevention and control measures. Internally, limit or prohibit group activities to reduce the risk of crowd gathering; externally, border control, and strict travel restrictions are in place. But the most common accept solution advocated by many countries is to lockdown the cities to prevent further infection. This caused a high unemployment rate and has widened existing divides between professionals, low-paid workers, people of different races, and the young. This study is trying to evaluate the economic damage by the pandemic specific to unemployment. Through the researches, the effects of unemployment caused by the pandemic are extensive and severe. The unemployment reveals the discrimination of American society and the hardship of low-paid workers. It also lowers students' efficiency.
\end{abstract}

Keywords: lockdown; pandemic; unemployment rate

COVID-19 may be the most influential word of the year in 2020, but its emergence has completely disrupted social order and development. Ten million people have been killed by COVID-19. Meanwhile, the COVID-19 continues to take a heavy toll on the global economy, especially in those European countries and the United States, the United States is considered to be the most serious one during the pandemic. The Eurozone also saw its biggest contraction in 25 years in the first quarter of 2020. In this article, I will make an in-depth analysis of the impact of COVID-19 on the world economy specific in the unemployment of people all over the world. Then countries are beginning to emerge from economic lockdown. As they do, the statistics show how different segments of the population have been affected by the pandemic, especially in the unemployment rate. The unemployment rate reached an unprecedented level since the 1930s, even above the height of the Great Recession. The newest released unemployment figures hit another record high with more than 30 million Americans claiming unemployment help in the last few weeks.

According to the research that was done in May, one out of every 3.9 people is unemployed which was 0.8 in February because the demand for workers decreased. Such an unemployment rate makes millions of people claimed that they do not have enough money to afford house fees and food. Because of the pandemic and lockdown, fewer people are likely to go out which means the real economy would suffer. For example, in New York, most commercial activities have banned, reducing the chance of people going out. Estimating to some economists, the metropolitan cities which depend on resources, tourism, and leisure and hospitality suffer the most. 
Yet most mainstream people still seem to believe that with a little more stimulation and an effective coronavirus vaccine, everything will be fine. But as some analysts have repeatedly pointed out, curing the coronavirus will not fix the economy. In the long run, the government's so-called "help" will only make things worse. The evidence is clear that the virus has widened existing divides between professionals, low-paid workers, people of different races, and young.

As COVID-19 continues to spread over the world, the bankruptcies of the United States have reached another high point in a decade. According to the recent study done by S\&P Global Market Intelligence, 424 companies had filed for bankruptcy which is more than in any comparable period since 2010. 31 companies were claiming bankruptcy only in 10 days. The reduction of employment also follows the bankruptcy of companies. For example, Dean \& Deluca is a food company in New York that filed for bankruptcy on March 31. Also, Apex Parks is a company of water parks claimed bankruptcy on April 8. These bankruptcies connect with the unemployment rate.

Many professionals can easily work at home, replacing one-to-one meetings with phone calls and group meetings with Zoom gatherings or Google hangouts. These "Zoomers" are mostly working on full pay and are currently being spared the daily commute. For them, the lockdown may be an inconvenience (particularly if they have children) but it is not a threat to their standards of living. There is still little opportunity cost for them. When they chose to not work outside, they gain the ability to work at home. The opportunity cost for this is that they cannot go outside because some people rather go outside to breathe fresh air or to take for a walk. For most others, however, the pandemic is a serious threat. Some are key workers, who have to attend their jobs and are at more risk from the virus. Others cannot work from home and have either lost their jobs or seen their incomes cut (despite help from government schemes). Many in this group were already in a weaker position than the Zoomers because they were in jobs with lower wages or less security. Some people in this less fortunate group can be dubbed the "zeros". In Britain, almost three-quarters of those on zero-hours contracts (people with the job that is lower wages or less security) are key workers or work in shut-down sectors, says the Resolution Foundation, a think-tank. Therefore, such opportunity cost appears: if they want to work, the risk for them getting disease increases. On the other hand, if they chose to not go to work, they would not get any money to feed themselves. At this point, one way is to get help from the government. Another way is asking for financial support from charity programs. By now over 17 million people have filed initial claims for unemployment insurance. For the people who get the virus, they have to stop work and get the treatment. However, this will cost a lot of money for them since they cannot work and cannot earn money. For example, after 5 months of retreatment, Chaney needed to pay three months' rent-free to his landlord. His family could not pay for this, thus he asked the help from the Chronicle Season of Sharing Fund. Otherwise, his family would have continued to rack up the endless debt. A further clue to the toll on the low-paid came from the latest American non-farm payroll figures. Average hourly earnings rose by $4.7 \%$ in April, the biggest monthly gain on record. That sounds like good news but it isn't. It is the result of low-wage workers losing jobs in sectors like hospitality. The rate of job layoffs is $10.4 \%$ in lowpaid jobs which is about 3times larger than the high-wage industries. The same trend can be seen in Britain, where the average wage of those in shut-down sectors is less than half of those working at home, according to the Resolution Foundation. The mortality rates make even grimmer news. The low-paid (and ethnic minorities) have suffered most. Figures from Britain's Office for National Statistics showed that death rates of security guards, care workers, and bus drivers were much higher than average, while those in "professional occupations" had death rates well below the mean.

Another great divide is between those already established in the workforce and Generation $\mathrm{Z}$-those born in the late 1990s and early 2000s who are now coming of age. They are entering a job market extremely hostile to their prospects. Around 30\% of British employees aged under 25 worked in one of 
the shut-down sectors, according to the Institute for Fiscal Studies, another think-tank, compared with $13 \%$ of those aged over 25 .

Students are also badly affected. Just like the Great Recession, as the pressure on adults increased because of unemployment, children tend to do worse in school and bear strains psychologically. Furthermore, college students are also influenced. For a start, it is harder to get work experience. In America, 22\% of employers have canceled internship offers, according to the National Association of Colleges and Employers. In the first week of May, just under 2,500 internships were posted on Monster.com, a recruitment website, compared with over 18,000 in the same week last year. Many of the remaining internships were in roles that could be done remotely. In Britain firms have cut entry-level jobs by $23 \%$, says the Institute of Student Employers, a recruiters' association. The shock of the pandemic will leave long-term scars. The Resolution Foundation estimates that the pandemic means those emerging from education this year will be less likely to have jobs in three years. The likelihood of being in employment would fall by $13 \%$ for graduates and $37 \%$ for those with the fewest qualifications. Before the pandemic, the demand for jobs for students keeps increasing every year, since more and more people can get educated. Due to the pandemic, however, most firms do not make a lot of profit and most firms decrease the number of jobs which means the supply for jobs decreases.

It is worth mentioning that although the unemployment rate would fell in the future automatically, estimated by many economists, people should not hold a positive attitude toward this. According to the research made in August, even though the rate of unemployment decreased from 12.8 percent in April to 6.9 percent in August among white people, the unemployment rate for black people almost unchanged. The unemployment rate for blacks still at 13.2 percent which is twice as much as white people. When someone argued that such an unequal rate of unemployment was not caused by the pandemic, but by the labor markets. They believed that the labor markets are created to be unequal and the studies from the past show that the rate of 2:1 employment rate between whites and blacks usually happened in the past even without the pandemic. However, during the pandemic, over 11 million people who lost their jobs, in the beginning, are still out of work, and a curiosity occurred. The increase in unemployment rates occurred to be the same in both races. The reason for this is the people who work for essential jobs are grouped with different kinds of people, and they are very hard to be dismissed since the essential jobs are significant to make sure the society is working. Nevertheless, these essential jobs are often having a low salary, do not have hazard pay, and they also need to expose themselves to the virus. Meanwhile, before taking these jobs, people should think about the opportunity cost. If they keep doing the job, the chance for them to get the virus will be greatly increased. On the other hand, if they decide not to continue the jobs, it is very hard for them to find another job at this specific time. This is not the consistent condition for African Americans, the truth is that they still face a disproportional ratio in unemployment rate compares with white people. Although many economists tried to find some way to solve such a problem, the only conclusion they got is: it is not an easy problem and cannot be solved in a short time.

In conclusion, as the unemployment rate keep increasing, it brings immense difficulties to everyone, especially to young, low-paid workers. Conflicts between professionals, low-paid workers, people with different races and young are created by the pandemic. Young people lose opportunity to find the jobs or get work experiences. Students cannot focus on their studying due to the hardship of the family. The difference between black and white becomes obviously during the unemployment rate which is kind of a discrimination.

This article combines many data from different studies to increase the specialization and accuracy of the article, and almost each study has explanation in case anyone can understand. However, the article did not contain many solutions for that such condition because it is a very controversial topic. Also, the study is mostly about United States, and it may not work well in explaining every country. 


\section{References:}

Center on Budget and Policy Priorities (2020). Tracking the COVID-19 Recession's Effects on Food, Housing, and Employment hardships. Retrieved from https://www.cbpp.org/research/poverty-andinequality/tracking-the-covid-19-recessions-effects-on-food-housing-and

Emily Pandise (2020). NEWS, From Friendly's to J. Crew, Main Street bankruptcies continue. Retrieved from https://www.nbcnews.com/business/consumer/which-major-retail-companies-have-filedbankruptcy-coronavirus-pandemic-hit-n1207866

Jason Furman (2020). PIIE, US unemployment is driven by a lack of employer demand, not an unwillingness to work. Retrieved https://www.piie.com/research/piie-charts/us-unemploymentdriven-lack-employer-demand-not-unwillingnesswork?gclid=CjwKCAiArIH BRB2EiwALfbH1FQFvJhJvmnhyUP50XVV7DNbPXHWHzTasDKmcDG 5pByOPuer1jqnxoCEfYQAvD BwE.

Maloney, W. and Taskin, T. (2020), 'Determinants of social distancing and economic activity during COVID-19: A global view', Policy Research Working Paper, No. 9242, World Bank, Washington, DC. Massey University could cut up to 100 science jobs. (2020). Retrieved from https://www.rnz.co.nz/news/national/427732/massey-university-could-cut-up-to-100-science-jobs

The New York Times (2020). When Parents Lose Their Jobs, Their Children Also Suffer. But Sometimes There's a Consolation. Retrieved from https://www.nytimes.com/2020/10/31/us/politics/unemployment-parents-children-coronavirus.html.

Nguyen, B. \& Wait, A. (2016). Essentials of Microeconomics. London, UK: Taylor \& Francis.

Olugbenga Ajilore, (2020). 'The Persistent Black-White Unemployment Gap Is Built into the Labor Market', Center for American Progress. Retrieved from https://www.americanprogress.org/issues/economy/news/2020/09/28/490702/persistent-black-whiteunemployment-gap-built-labor-market/

Stephanie Aaronson and Francisca Alba (2020). The unemployment impacts of COVID-19: lessons from the Great Recession. Retrieved from https://www.brookings.edu/blog/up-front/2020/04/15/theunemployment-impacts-of-covid-19-lessons-from-the-great-recession/.

Vanessa Arredondo (2020). Help with Paying off Bills Relieves Family's Worries, San Francisco Chronicle. Retrieved from https://www.sfchronicle.com/bayarea/article/Help-with-paying-off-billsrelieves-family-s-15786022.php 